\title{
Assessing the distribution of estrildid finches on Vanuatu using local knowledge
}

\author{
A.C. BIRCHENOUGH, G.W. DOUGLAS and S.M. EVANS
}

\section{Summary}

A rapid appraisal technique, using local people's knowledge of bird life, was used to map the distribution and assess conservation needs of estrildid finches on Vanuatu. Most ni-Vanuatu, especially men, have good knowledge of the local bird fauna. Not surprisingly, therefore, there was close agreement between the distributions of finches predicted from the use of this technique and from field records of the birds. The data suggest that the ranges of two endemic subspecies, Royal Parrot Finch Erythrura cyanovirens regia and Blue-faced Parrot Finch Erythrura trichroa cyanofrons, have declined in recent years. Royal Parrot Finch, in particular, should be given high conservation priority. It now occupies a tiny global range and is believed to be particularly vulnerable to further habitat change.

\section{Introduction}

The Convention on Biological Diversity, which was signed at the United Nations Conference on Environment and Development (the Earth Summit) in Rio de Janeiro in 1992, presents a particular challenge to small island states. Many islands are spectacularly rich in biodiversity but their biotas are also fragile. They support high numbers of endemic and restricted-range species (Stattersfield et al. 1998) but, as a result of their small size, populations are highly vulnerable to either human-induced catastrophes, such as habitat destruction and the introduction of alien invasive species, or natural ones, such as cyclones. The impact can be seen on avifauna; $93 \%$ of the 176 bird species and subspecies that have become extinct since 1600 were island forms (King 1981) and island species now account for more than $50 \%$ of endangered birds (King 1985).

The group of islands that form Vanuatu are unique because they are at a crossroad, where three routes of colonization of the Pacific meet one another (Diamond and Marshall 1976). Seven of the 74 species of land or freshwater birds are endemic to the islands and several of them have restricted ranges, even within the islands (Bregulla 1992). The ecology of the avifauna is nevertheless poorly known and the Government of Vanuatu has insufficient resources to undertake extensive research. An additional problem is that most of the islands are covered by dense rainforest. This increases their conservation value but they are difficult habitats in which to work and therefore assess biodiversity.

A global challenge to avian research is that there are insufficient resources, either in terms of scientific manpower or funds, to undertake detailed ecological studies of the 1,186 bird species that have been listed as endangered (BirdLife 
International 2000). Rapid appraisal techniques, which permit cost-effective environmental assessments and provide bases on which to assess priorities for future research, are particularly valuable in circumstances of this kind. A number have been developed in recent years, including assessments of human-induced damage to mollusc assemblages of mangrove forests (Skilleter 1996), invertebrate biodiversity (Oliver and Beattie 1996), status of lowland tropical rainforests (Turner et al. 1996), fungal diversity (Cannon 1997), early warning indications of wetland degradation (Van Dam et al. 1998) and the status and health of African lake fisheries (Preikshot et al. 1998). The object of the present study was to develop a rapid appraisal technique that could be used to map the distribution of birds on Vanuatu (and in similar situations elsewhere). It is based on the abilities of the people of Vanuatu to recognize species of birds that occur locally. The method has been developed for the estrildid finches but it is intended to be a model that can be used for bird species in other locations where fieldwork is difficult but local people have a good knowledge of their wildlife.

There are believed to be two indigenous estrildids on Vanuatu (Bregulla 1992). Royal Parrot Finch Erythrura cyanovirens comprises two subspecies: E. cyanovirens cyanovirens is endemic to Western Samoa and E. cyanovirens regia is endemic to Vanuatu. Bregulla (1992) described the latter as common on some islands but expressed concern that it may be declining due to habitat change on others, and that it may already be extinct on Aneityum Island. It is listed as Vulnerable by BirdLife International (2000) (who accord it full species status Erythrura regia). Blue-faced Parrot Finch Erythrura trichoa comprises 10 subspecies, distributed from north-eastern Australia, through the Indo-Pacific to island groups in the western Pacific Ocean. The subspecies E. trichoa cyanofrons is endemic to Vanuatu and the Loyalty Islands (Ziswiler et al. 1972). It occurs on several islands of Vanuatu but, although it is said to be common on Efate, it is uncommon on most of them (Bregulla 1992).

There are also three introduced estrildid species on Vanuatu (Bregulla 1992). Common Waxbill Estrilda astrild is an African species, which became established on the islands of Efate and Santo, probably as a result of escapes of captive birds from aviaries. It is common in open rough grass on Efate (Bregulla 1992). Chestnut-breasted Mannikin Lonchura castaneothorax is a native of Australia and New Guinea but became established on Santo during the past three or four decades, evidently as a result of escapees from aviaries (Bregulla 1992). Black-headed Mannikin Lonchura malacca is a native of South-East Asia but has become established on Santo after individuals escaped from an aviary in about 1960 (Bregulla 1992).

Additional introduced species have been reported on occasions, namely Redbrowed Firetail Neochmia temporalis, Red Avadavat Amandava amandava and Redheaded Parrot Finch Erythrura psittacea, but none of them appears to have become permanently established (Bregulla 1992).

The rapid appraisal technique involved showing people colour illustrations (paintings or photos) of estrildids (and other birds) (taken from Bregulla 1992) and asking them whether or not the species occurred locally (i.e. on their island). However, in order to restrict analyses to people who had good knowledge of the local bird life, and could therefore provide reliable information, they were also asked to respond to illustrations of a range of non-estrildid species, some of 
which were resident on their island and some of which were non-resident. Subsequent analyses were then confined to people who were judged to have "good knowledge" on the basis of their responses. Distributions of estrildids predicted on the basis of the appraisal technique using local knowledge were "groundtruthed" from data obtained from field recordings.

\section{Methods}

Study area

Vanuatu consists of about 80 islands, and has a population of about 140,000 people. The main centres of population are the towns of Port Vila and Luganville, on the islands of Efate and Santo (more fully Espirito Santo) respectively (Figure 1). There has been some urban and agricultural development on these two islands but most people (ni-Vanuatu) live in small villages and farm at subsistence level, tending partly cleared areas of forest, known as village gardens. They rear some animals, such as pigs, chickens and cattle. Village gardens are cultivated mostly by the men, and may be at distances of several $\mathrm{km}$ from the villages themselves.

The surveys undertaken in the present study were made on 12 of the larger islands in the central and southern parts of Vanuatu: Aneityum, Tanna, Efate, Emae, Tongoa, Epi, Ambrym, Malakula, Pentecost, Ambae, Maewo and Santo (Figure 1). The study was carried out during the period June-September 1999.

\section{Knowledge of bird life}

Interviews were carried out (by the authors) at 61 villages (between four and eight on each island), and approximately 10 adults (range 8-12) were interviewed at each of them (Table 1). We were always accompanied by a local guide who spoke English and the national pidgin language, bislama. This was the respondents' second language, after their tribal language. Initially the head of each village was approached for permission to carry out the interviews. This was invariably given willingly. The interviewees were either selected by us, normally the nearest adults to us, or were "volunteered" by the head of the village. The guide explained the procedure to them.

The first step in the procedure was to distinguish between those interviewees who had "good knowledge" of local birds and those who had "poor knowledge". Interviewees were tested on a one-to-one basis and interviews were conducted either in English or French (where this was spoken as the third language). However, the spoken word was minimal. Interviewees were simply asked to respond "yes" or "no" (or "oui" or "non"), separately to each of the colour illustrations depending on whether or not they believed that the species occurred on the island. Each person was tested on each of 35 (non-estrildid) bird species, all of which occur on Vanuatu (Table 2). However, the ranges of many of them are restricted to part of the country (i.e. some of the islands) only. On each island, bird species were classified as resident (i.e. had been recorded on the particular island either by Bregulla (1992) or in the present study) or non-resident (i.e. for which there were no records on that island). A "yes" response was considered 


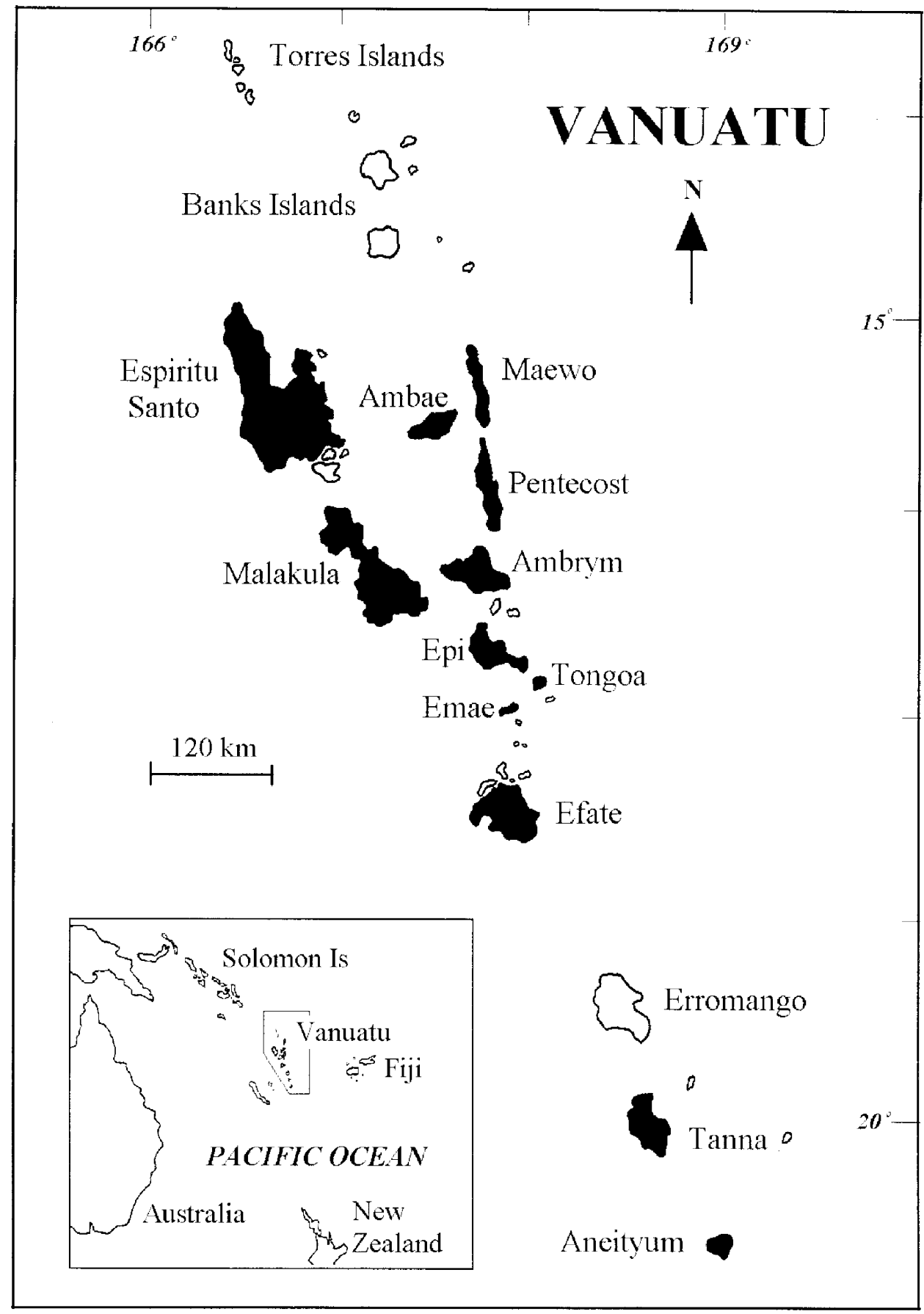

Figure 1. A map of Vanuatu. Islands which were surveyed are shown in black. 
Table 1. Numbers of people interviewed at villages visited on islands in Vanuatu during the period June-September 1999.

\begin{tabular}{ll}
\hline Island & Villages and numbers of people interviewed \\
\hline Aneityum & Analgawat (11); Anawonse (11); Isomoso (8); Umetch (10) \\
Tanna & Fetukai (11); Ikeuti (12); Manuapen (9); Yaneumakei (12); Yetpaleniel (12) \\
Efate & Epao (10); Epule (10); Errango (10); Eton (9); Malapoa (10); Mele (11); Paunag- \\
& isu (12); Port Vila (14); Ulei (10) \\
Emae & Makatea (11); Mangita (10); Sesake (11); Tapakoro (12) \\
Tongoa & Etua (10); Kurumanbae (12); Lumbukuti (12); Mangarisu (11); Rafenga (9) \\
Epi & Anduan (9); Ngala (8); Rovo Bay (11); Vaemali (11); Vovo (10) \\
Ambym & Biap (9); Maronon (10); Meltugan (10); Ranon (10) \\
Malakula & Fatapo (12); Metenua (9); Rambuan (11); Tenbimbi (7); Walarano (10) \\
Pentecost & Abwantun (9); Ena (10); Melsisi (9); Pangi (10); Rangususu (10) \\
Ambae & Ambanga (9); Lovuniviti (10); Nanako (11); Sara Lokambu (10); Walaha (11) \\
Maewo & Kerembei (10); Naone (9); Nasawa (9); Qatiawol (10); Rognawo (10) \\
Santo & Butmas (10); Kholeu (8); Matantas (9); Narango (10); Palon (11); Sarede (10) \\
\hline
\end{tabular}

to be a correct answer to the sight of an illustration of a resident species. A "no" response to a non-resident species was also correct. Conversely, "no" responses to residents, and "yes" responses to non-residents, were incorrect responses. An interviewee was considered to have "good knowledge" based on the satisfaction of two criteria: $>50 \%$ correct answers to resident species and $>50 \%$ correct answers to non-resident species. Those with "poor knowledge" (i.e. who failed to reach either one or both of these criteria) were subdivided into three categories: (i) those who tended to answer "yes" to all illustrations shown to them, and therefore scored $>50 \%$ correct responses to residents but $<50 \%$ correct to non-residents; (ii) those who tended to answer "no" to all illustrations, and therefore scored $<50 \%$ correct responses to residents but $>50 \%$ correct responses to non-residents; and (iii) those who failed to satisfy either criterion $(<50 \%$ correct answers to both residents and non-residents). This enabled a comparison to be made of the strategies used by males and females with "poor knowledge" in responding to the illustrations. It is possible that some birds have either increased or decreased their ranges since the publication of Bregulla's book in 1992 (which describes the ranges of Vanuatuan birds from information gathered between 1959 and 1969). This could lead to correct answers to a newly arrived resident on an island (i.e. it is present) being scored as incorrect. Records were therefore kept of all sightings of the birds whose illustrations were used in the tests in order to give some indication of the extent to which the distributions of species had changed in the past three decades.

The second stage of the procedure was to obtain information on the local presence or absence or estrildids. Each interviewee was shown colour illustrations of each of the five estrildids that were believed to occur on Vanuatu, and asked to respond in the same way (as above). In the subsequent analyses, only data from those people who achieved the criteria for "good knowledge" were included. Statistical comparisons were made using the Chi-square test between the numbers of "yes": "no" responses for each species on each island with the numbers 
Table 2. Resident and non-resident species on Vanuatuan islands visited during this study (JuneSeptember 1999) based on information in Bregulla (1992) and sightings of species, order as in Bregulla (1992). Islands indicated as follows: 1, Aneityum; 2, Tanna; 3, Efate; 4, Emae; 5, Tongoa; 6, Epi; 7, Ambrym; 8, Malakula; 9, Pentecost; 10, Ambae; 11, Maewo; 12, Santo. $\bullet$, recorded on that island by Bregulla (1992) and in present study; $\circ$, recorded on that island by Bregulla (1992) only; $\bullet$, recorded on that island in present study only.

\begin{tabular}{|c|c|c|c|c|c|c|c|c|c|c|c|c|}
\hline Species & 1 & 2 & 3 & 4 & 5 & 6 & 7 & 8 & 9 & 10 & 11 & 12 \\
\hline $\begin{array}{l}\text { Red-bellied Fruit Dove } \\
\text { Ptilinopus greyii }\end{array}$ & $\bullet$ & $\bullet$ & $\bullet$ & $\bullet$ & $\bullet$ & - & $\bullet$ & $\bullet$ & $\bullet$ & $\bullet$ & $\bullet$ & $\bullet$ \\
\hline $\begin{array}{l}\text { Vanuatu Fruit Dove } \\
\text { Ptilinopus tannensis }\end{array}$ & $\bullet$ & $\bullet$ & $\bullet$ & $\bullet$ & $\bullet$ & $\bullet$ & $\bullet$ & $\bullet$ & $\bullet$ & $\bullet$ & $\bullet$ & $\bullet$ \\
\hline $\begin{array}{l}\text { Pacific Imperial Pigeon } \\
\text { Ducula pacifica }\end{array}$ & $\bullet$ & $\bullet$ & $\bullet$ & $\bullet$ & $\bullet$ & $\bullet$ & $\bullet$ & $\bullet$ & $\bullet$ & $\bullet$ & $\bullet$ & $\bullet$ \\
\hline $\begin{array}{l}\text { Vanuatu Mountain Pigeon } \\
\text { Ducula bakeri }\end{array}$ & & & & & & & 0 & & 0 & 0 & $\circ$ & 0 \\
\hline $\begin{array}{l}\text { White-throated Pigeon } \\
\text { Columbia vitiensis }\end{array}$ & 0 & $\bullet$ & 0 & 0 & 0 & O & 0 & $\bullet$ & 0 & 0 & 0 & $\circ$ \\
\hline $\begin{array}{l}\text { Rufous-brown Pheasant Dove } \\
\text { Macropygia mackinlayi }\end{array}$ & $\bullet$ & $\bullet$ & $\bullet$ & $\bullet$ & $\bullet$ & $\bullet$ & $\bullet$ & $\bullet$ & 0 & $\bullet$ & 0 & $\bullet$ \\
\hline $\begin{array}{l}\text { Green-winged Ground Dove } \\
\text { Chalophaps indica }\end{array}$ & $\bullet$ & $\bullet$ & $\bullet$ & $\bullet$ & $\bullet$ & $\bullet$ & $\bullet$ & $\bullet$ & $\bullet$ & $\bullet$ & $\bullet$ & $\bullet$ \\
\hline $\begin{array}{l}\text { Santa Cruz Ground Dove } \\
\text { Gallicolumbia santacrucis }\end{array}$ & & & & & & & & & & & & o \\
\hline $\begin{array}{l}\text { Rainbow Lorikeet } \\
\text { Trichoglossus haematodus }\end{array}$ & $\bullet$ & $\bullet$ & $\bullet$ & $\bullet$ & $\bullet$ & $\bullet$ & $\bullet$ & $\bullet$ & $\bullet$ & $\bullet$ & $\bullet$ & $\bullet$ \\
\hline $\begin{array}{l}\text { Green Palm Lorikeet } \\
\text { Charmosyna palmarum }\end{array}$ & 0 & 0 & 0 & 0 & 0 & 0 & 0 & $\bullet$ & ○ & $\bullet$ & ० & 0 \\
\hline $\begin{array}{l}\text { White-collared Kingfisher } \\
\text { Halcyon chloris }\end{array}$ & $\bullet$ & $\bullet$ & $\bullet$ & $\bullet$ & $\bullet$ & $\bullet$ & $\bullet$ & $\bullet$ & $\bullet$ & $\bullet$ & $\bullet$ & $\bullet$ \\
\hline $\begin{array}{l}\text { Vanuatu Kingfisher } \\
\text { Halcyon farquhari }\end{array}$ & & & & & & & & 0 & & & $\diamond$ & 0 \\
\hline $\begin{array}{l}\text { Melanesian Cuckoo-shrike } \\
\text { Coracina caledonica }\end{array}$ & & & & & & & & O & & & & $\bullet$ \\
\hline $\begin{array}{l}\text { Polynesian Triller } \\
\text { Lalage maculosa }\end{array}$ & & & o & $\bullet$ & $\bullet$ & $\bullet$ & & $\bullet$ & & & & $\bullet$ \\
\hline $\begin{array}{l}\text { Long-tailed Triller } \\
\text { Lalage leucopyga }\end{array}$ & $\bullet$ & $\bullet$ & $\bullet$ & 0 & 0 & 0 & $\bullet$ & $\bullet$ & 0 & $\bullet$ & 0 & $\bullet$ \\
\hline $\begin{array}{l}\text { Island Thrush } \\
\text { Turdus poliocephalus }\end{array}$ & 0 & 0 & 0 & 0 & & O & o & $\bullet$ & 0 & O & 0 & $\bullet$ \\
\hline $\begin{array}{l}\text { Scarlet Robin } \\
\text { Petroica multicolor }\end{array}$ & 0 & 0 & 0 & 0 & 0 & 0 & $\bullet$ & $\bullet$ & & $\bullet$ & 0 & $\bullet$ \\
\hline $\begin{array}{l}\text { Golden Whistler } \\
\text { Pachycephala pectoralis }\end{array}$ & • & & 0 & 0 & 0 & • & 0 & • & 0 & 0 & • & $\bullet$ \\
\hline $\begin{array}{l}\text { Southern Shrikebill } \\
\text { Clytorhynchus pachycephaloides }\end{array}$ & 0 & & 0 & 0 & 0 & 0 & & 0 & 0 & 0 & 0 & $\bullet$ \\
\hline $\begin{array}{l}\text { Broad-billed Flycatcher } \\
\text { Myiagra caledonica }\end{array}$ & • & • & $\bullet$ & • & $\bullet$ & • & $\bullet$ & $\bullet$ & 0 & $\bullet$ & $\bullet$ & $\bullet$ \\
\hline $\begin{array}{l}\text { Vanuatu Flycatcher } \\
\text { Neolalage banksiansi }\end{array}$ & & & 0 & & & 0 & $\bullet$ & • & 0 & $\bullet$ & $\bullet$ & $\bullet$ \\
\hline $\begin{array}{l}\text { Grey Fantail } \\
\text { Rhipidura fuliginosa }\end{array}$ & $\bullet$ & & $\bullet$ & $\bullet$ & $\bullet$ & $\bullet$ & $\bullet$ & $\bullet$ & $\bullet$ & $\bullet$ & $\bullet$ & $\bullet$ \\
\hline $\begin{array}{l}\text { Spotted Fantail } \\
\text { Rhipidura spilodera }\end{array}$ & & & 0 & 0 & 0 & 0 & 0 & $\bullet$ & 0 & $\bullet$ & • & $\bullet$ \\
\hline $\begin{array}{l}\text { Fantail Warbler } \\
\text { Gerygone flavolateralis }\end{array}$ & & & & • & & 0 & 0 & 0 & $\bullet$ & 0 & $\circ$ & 0 \\
\hline
\end{tabular}


Table 2. Continued.

\begin{tabular}{|c|c|c|c|c|c|c|c|c|c|c|c|c|}
\hline Species & 1 & 2 & 3 & 4 & 5 & 6 & 7 & 8 & 9 & 10 & 11 & 12 \\
\hline $\begin{array}{l}\text { Thicket Warbler } \\
\text { Cichlornis whitneyi }\end{array}$ & & & & & & & & & & & & $\bullet$ \\
\hline $\begin{array}{l}\text { Mountain Honeyeater } \\
\text { Phylidronis notablis }\end{array}$ & & & & & & O & ○ & 0 & O & O & 0 & $\circ$ \\
\hline $\begin{array}{l}\text { Silver-eared Honeyeater } \\
\text { Lichmera incana }\end{array}$ & & $\bullet$ & $\bullet$ & $\bullet$ & $\bullet$ & $\bullet$ & $\bullet$ & $\bullet$ & & $\bullet$ & & \\
\hline $\begin{array}{l}\text { Cardinal Honeyeater } \\
\text { Myeomeia cardinalis }\end{array}$ & $\bullet$ & $\bullet$ & O & o & $\bullet$ & $\bullet$ & $\bullet$ & $\bullet$ & $\bullet$ & • & • & $\bullet$ \\
\hline $\begin{array}{l}\text { Vanuatu White-eye } \\
\text { Zosterops flavifrons }\end{array}$ & $\bullet$ & $\bullet$ & $\bullet$ & $\bullet$ & $\bullet$ & $\bullet$ & $\bullet$ & $\bullet$ & $\bullet$ & $\bullet$ & $\bullet$ & $\bullet$ \\
\hline $\begin{array}{l}\text { Grey-backed White-eye } \\
\text { Zosterops lateralis }\end{array}$ & & ○ & $\bullet$ & $\bullet$ & $\bullet$ & $\bullet$ & $\bullet$ & $\bullet$ & $\bullet$ & ○ & $\circ$ & $\bullet$ \\
\hline $\begin{array}{l}\text { House Sparrow } \\
\text { Passer domesticus } \\
\text { Common Waxbill } \\
\text { Estrilda astrild }\end{array}$ & & & $\bullet$ & & & & & & & & & \\
\hline $\begin{array}{l}\text { Chestnut-breasted Mannikin } \\
\text { Lonchura castaneothorax } \\
\text { Black-headed Mannikin } \\
\text { Lonchura malacca }\end{array}$ & & & & & & & & & & & & $\begin{array}{l}\bullet \\
\bullet\end{array}$ \\
\hline $\begin{array}{l}\text { Blue-faced Parrot Finch } \\
\text { Erythrura trichroa }\end{array}$ & o & ० & $\bullet$ & O & & & ० & & & & $\circ$ & \\
\hline $\begin{array}{l}\text { Royal Parrot Finch } \\
\text { Erythrura cyanovirens }\end{array}$ & o & & $\bullet$ & $\bullet$ & $\bullet$ & $\bullet$ & ० & o & $\circ$ & 0 & & 0 \\
\hline $\begin{array}{l}\text { Santo Mountain Starling } \\
\text { Apolonis santovestris }\end{array}$ & & & & & & & & & & & & O \\
\hline $\begin{array}{l}\text { Rusty-winged Starling } \\
\text { Aplonis zelandicus }\end{array}$ & & & O & & & & O & $\circ$ & $\circ$ & ० & & $\circ$ \\
\hline $\begin{array}{l}\text { Indian Mynah } \\
\text { Acrithodtheres tristis }\end{array}$ & & $\bullet$ & $\bullet$ & & & $\bullet$ & & & & & & $\bullet$ \\
\hline $\begin{array}{l}\text { White br'sted Woodswallow } \\
\text { Artamus leucorhynchus }\end{array}$ & $\bullet$ & $\bullet$ & $\bullet$ & $\bullet$ & $\bullet$ & $\bullet$ & $\bullet$ & $\bullet$ & $\bullet$ & $\bullet$ & $\bullet$ & $\bullet$ \\
\hline
\end{tabular}

for the same species for those islands (summated) on which the species had never been recorded (Table 2).

A problem in conducting the interviews was caused by the enthusiasm of children to be involved. It was often necessary for one interviewer to lead them away as a group and carry out mock interviews, while adults were interviewed on a 1:1 basis by a second interviewer. There was also a tendency for people who were not being interviewed to look on during an interview, in which case some interviewees would seek help from others, through verbal confirmation, eye contact or other use of body language, before responding. Only information from those interviews that were conducted with adults on their own, without the possibility of collusion, were included in the analysis of data.

Ground-truthing the data: field counts of estrildids

Formal counts of estrildids were made on each of the islands visited. They were made in sessions lasting for one hour, during which the observer remained sta- 
tionary at a fixed place. Records were made in four habitat types on each of the islands: forest, cleared forest, village gardens and within the villages themselves. An additional two habitat types, open agricultural land and urban areas, were surveyed on Efate and Santo. Each recording was made at a different site. The knowledge of villagers was often used in selecting specific recording sites. On each island, the numbers of recordings were the same for each habitat type. They were as follows (numbers of sessions for each habitat type are shown in parentheses): Aneityum (5), Tanna (5), Efate (10), Emae (5), Tongoa (6), Epi (10), Ambrym (7), Malakula (7), Pentecost (8), Ambae (8), Maewo (8), and Santo (6).

\section{Results}

\section{Local knowledge of birds}

The majority of ni-Vanuatu interviewed were familiar with the resident birds on their islands. They usually responded to the colour illustrations of them quickly and confidently. Conversely, they mostly responded to illustrations of nonresident species by indicating that they were not present on the island. Most people who were interviewed satisfied both criteria for good knowledge (responding correctly to most of the illustrations of both resident and nonresident species). However, the proportion of males reaching these criteria $(87.2 \%)$ was higher than that in females $(58.0 \%)$. This difference was evident in data for each of the islands considered separately $(P<0.001 ; n=12$; Wilcoxon matched-pairs signed-ranks test) (Table 3 ). There was also a gender difference in the way in which individuals with poor knowledge responded to the illustrations. Females with poor knowledge tended to answer "yes" to illustrations of both resident and non-resident species, while males with poor knowledge tended to answer "no" to illustrations in both of these categories. Differences in the numbers of males and females with poor knowledge responding in these two ways were significant for the data overall $\left(\chi^{2}=25.49, d f=2, P<0.001\right.$; Chi-square test $)$ and data for each of the islands considered separately $(P<0.001$; Wilcoxon matched-pairs signed-ranks test).

There has evidently been little change in the ranges occupied by Vanuatuan bird species during the past 30 years so that the definitions of "resident" and "non-resident" bird, based on Bregulla's (1992) records, were mostly sound. Overall, 30 ( $85.7 \%)$ of the 35 species (excluding estrildid finches) whose illustrations were used to assess knowledge of bird life, were recorded during the study period, many of them on several islands (Table 2). All sightings (with two exceptions) were of species on islands where they had previously been recorded by Bregulla (1992).

Two species were sighted on islands on which they had not been previously recorded (Table 2), and were therefore new island records. A single Vanuatu Kingfisher Halcyon farquhari was observed on Maewo in montane forest close to the village of Rognawo. Two Silver-eared Honeyeaters Lichmera incana were observed in a garden in the coastal village of Nanako on Ambae.

\section{Distributions of estrildids based on local knowledge and field observations}

Estrildid finches are small, and in the case of Common Waxbill, Chestnutbreasted Mannikin and Black-headed Mannikin, dull coloured, in comparison 
Table 3. Numbers of Vanuatuan men and women who were categorized as having either "good knowledge" or "poor knowledge" of local bird life. Those with poor knowledge tended to respond in three different ways: (i) "yes" to all photographs; (ii) "no" to them; or (iii) a mixtures of "yes" and "no" responses.

\begin{tabular}{|c|c|c|c|c|c|c|}
\hline \multirow{2}{*}{ Island } & \multirow{2}{*}{$\begin{array}{l}\text { Sample } \\
\text { size }\end{array}$} & \multirow{2}{*}{$\begin{array}{c}\text { Good } \\
\text { knowledge } \\
n\end{array}$} & \multicolumn{4}{|c|}{ Poor knowledge } \\
\hline & & & $n$ & $\begin{array}{l}\text { Mostly } \\
\text { yes }\end{array}$ & $\begin{array}{l}\text { Mostly } \\
\text { no }\end{array}$ & Yes/no \\
\hline
\end{tabular}

\begin{tabular}{|c|c|c|c|c|c|c|}
\hline \multicolumn{7}{|l|}{ Males } \\
\hline Aneityum & 27 & 23 & 4 & 3 & 1 & $\mathrm{O}$ \\
\hline Tanna & 41 & 33 & 8 & 5 & 3 & o \\
\hline Efate & 62 & 50 & 12 & 2 & 10 & $\mathrm{O}$ \\
\hline Emae & 34 & 29 & 5 & 1 & 4 & o \\
\hline Tongoa & 39 & 38 & 1 & o & 1 & $\mathrm{O}$ \\
\hline Epi & 34 & 31 & 3 & o & 3 & $\mathrm{O}$ \\
\hline Ambrym & 25 & 24 & 1 & $\mathrm{O}$ & 1 & $\mathrm{O}$ \\
\hline Malakula & 35 & 34 & 1 & o & 1 & $\mathrm{O}$ \\
\hline Pentecost & 36 & 32 & 3 & o & 3 & 1 \\
\hline Ambae & 36 & 32 & 4 & 2 & 2 & o \\
\hline Maewo & 32 & 28 & 4 & 2 & 1 & 1 \\
\hline Santo & 38 & 33 & 5 & 3 & 2 & o \\
\hline Total & 444 & 387 & 57 & 18 & 37 & 2 \\
\hline$\%$ & & 87.2 & 12.8 & 4.1 & 8.3 & 0.5 \\
\hline \multicolumn{7}{|l|}{ Females } \\
\hline Aneityum & 13 & 9 & 4 & 4 & o & $\mathrm{O}$ \\
\hline Tanna & 15 & 12 & 3 & 3 & o & $\mathrm{o}$ \\
\hline Efate & 22 & 8 & 14 & 9 & 5 & o \\
\hline Emae & 11 & 6 & 5 & 3 & 2 & $\mathrm{O}$ \\
\hline Tongoa & 15 & 10 & 5 & 2 & 2 & 1 \\
\hline Epi & 15 & 9 & 6 & 5 & 1 & $\mathrm{O}$ \\
\hline Ambrym & 13 & 10 & 3 & 3 & o & $\mathrm{O}$ \\
\hline Malakula & 14 & 9 & 5 & 4 & 1 & $\mathrm{O}$ \\
\hline Pentecost & 12 & 7 & 5 & 2 & 3 & $\mathrm{O}$ \\
\hline Ambae & 15 & 7 & 8 & 6 & 2 & o \\
\hline Maewo & 16 & 8 & 8 & 7 & 1 & o \\
\hline Santo & 20 & 10 & 10 & 9 & o & 1 \\
\hline Total & 181 & 105 & 76 & 57 & 17 & 2 \\
\hline$\%$ & & 58.0 & 42.0 & 31.5 & 9.4 & 1.1 \\
\hline
\end{tabular}

with most of the other "test" species in this study. Nevertheless, most ni-Vanuatu were able to recognize them. There were $>40 \%$ "yes" responses to Chestnutbreasted Mannikin and Black-headed Mannikin on Santo, and Common Waxbill on Efate, the only islands on which they were actually observed (Table 4). This compares with a mean of $<12 \%$ for these species on other islands where they do not occur (Table 4). Similarly, Royal Parrot Finch and Blue-faced Parrot Finch obtained high scores (> 37\% "yes" responses) on those islands were they were sighted, compared with means of $<10 \%$ on other islands. People who were interviewed were often able to provide additional information about species, such as places where they were likely to be seen and their feeding habits. This included, for example, information that Royal Parrot Finch fed on figs and could be found wherever there were trees with ripe fruits, Chestnut-breasted Mannikin 
Table 4. Percentages of positive ("yes") responses to colour illustrations of five estrildids in people with "good knowledge".

\begin{tabular}{|c|c|c|c|c|c|c|}
\hline Island & $n$ & $\begin{array}{l}\text { Common } \\
\text { Waxbill }\end{array}$ & $\begin{array}{l}\text { Royal } \\
\text { Parrot } \\
\text { Finch }\end{array}$ & $\begin{array}{l}\text { Blue-faced } \\
\text { Parrot } \\
\text { Finch }\end{array}$ & $\begin{array}{l}\text { Chestnut- } \\
\text { breasted } \\
\text { Mannikin }\end{array}$ & $\begin{array}{l}\text { Black-headed } \\
\text { Mannikin }\end{array}$ \\
\hline Aneityum & 32 & 9.4 & 12.5 & $21.9^{*}$ & 9.4 & 12.5 \\
\hline Tanna & 45 & 11.1 & $13 \cdot 3$ & $28.9^{* * *}$ & 15.6 & 15.6 \\
\hline Efate & 58 & $48.3^{* * *}$ & $37.9^{* * *}$ & $46.6^{* * *}$ & 8.6 & 6.9 \\
\hline Emae & 35 & $\mathrm{O}$ & $60.0^{* * *}$ & 2.9 & 2.9 & 2.9 \\
\hline Tongoa & 48 & 4.2 & $68.8^{* * *}$ & 10.4 & 4.2 & $\mathrm{o}$ \\
\hline Epi & 40 & 10.0 & $50.0^{* * *}$ & 5.0 & 20.0 & 15.0 \\
\hline Ambrym & 34 & 2.9 & $38.2^{* * *}$ & 8.8 & 14.7 & 14.7 \\
\hline Malakula & 43 & 8.7 & 16.3 & $9 \cdot 3$ & 14.0 & $20.9^{*}$ \\
\hline Pentecost & 39 & 9.0 & 12.8 & $7 \cdot 7$ & 20.5 & 10.3 \\
\hline Ambae & 39 & o & 10.3 & $7 \cdot 7$ & 10.3 & 2.6 \\
\hline Maewo & 36 & 11.1 & 5.6 & 8.3 & 11.1 & 2.8 \\
\hline Santo & 43 & 14.0 & 11.6 & 4.8 & $41.9^{* * *}$ & $67 \cdot 4^{* * *}$ \\
\hline
\end{tabular}

Statistical comparisons were based on numbers of yes : no answers on each of the islands separately with those summated for all of the islands on which the species had not been recorded: ${ }^{*} P<0.05$; *** $P<0.001$; Chi-square test.

and Black-headed Mannikin could often be seen foraging on seeding grasses on tracks or roadside verges, and Blue-faced Parrot Finch and Common Waxbill fed on grasses on the golf course at Mele (Efate).

Not surprisingly, there was close conformity between the results obtained from analyses of local knowledge and sightings of estrildids from field observations. They suggested that each species had a patchy distribution and was restricted to relatively few islands, as follows:

(i) A high proportion of local people $(>37 \% ; P<0.001$ in each case) claimed that estrildids were present on the following islands (Table 4 ), and in each case there were actual sightings of them during formal field counts of birds (Table 5): Common Waxbill on Efate; Royal Parrot Finch on Efate, Emae, Tongoa

Table 5. Mean numbers of sightings per hour of estrildids during observations in six habitat types. There were no sightings on those islands that are not included in the Table.

\begin{tabular}{lclllll}
\hline Island & Forest & $\begin{array}{l}\text { Cleared } \\
\text { forest }\end{array}$ & $\begin{array}{l}\text { Village } \\
\text { gardens }\end{array}$ & Village & $\begin{array}{l}\text { Agricultural } \\
\text { land }\end{array}$ & Urban land \\
\hline $\begin{array}{l}\text { Common Waxbill } \\
\text { Efate }\end{array}$ & 0 & 61.3 & 0.8 & 0 & 54.3 & 0 \\
Royal Parrot Finch & & & & & & \\
Efate & 0.4 & 0 & 0 & 0.3 & 0 & 0 \\
Emae & 0.4 & 0 & 0 & 1.0 & 0 & 0 \\
Tongoa & 0.8 & 0 & 0 & 0 & 0 & 0 \\
Epi & 0.6 & 0 & 0 & 0 & 0 & 0 \\
Blue-faced Parrot & & & & & & \\
Finch & 0.3 & 0.5 & 0 & 0 & 0 & 0 \\
Efate & & & & & & 0 \\
Black-headed & 0 & 0 & 0 & 0 & 3.6 & 0 \\
Mannikin & & & &
\end{tabular}


Table 6. Mean percent "yes" responses to colour illustrations of estrildids on Vanuatuan islands: (i) on which species have never been recorded; (ii) those on which Bregulla (1992) recorded them but they were not observed in the present study; and (iii) those on which they have been recorded both by Bregulla (1992) and in the present study.

\begin{tabular}{|c|c|c|c|c|c|c|}
\hline & \multicolumn{2}{|c|}{$\begin{array}{c}\text { Islands where species } \\
\text { never recorded }\end{array}$} & \multicolumn{2}{|c|}{$\begin{array}{l}\text { Islands where species } \\
\text { recorded by Bregulla } \\
\text { (1992) but not in } \\
\text { present study }\end{array}$} & \multicolumn{2}{|c|}{$\begin{array}{c}\text { Islands where species } \\
\text { recorded by Bregulla } \\
\text { (1992) and in present } \\
\text { study }\end{array}$} \\
\hline & $n$ & $\begin{array}{l}\text { Mean } \\
\text { percentage } \\
\text { "yes" }\end{array}$ & $n$ & $\begin{array}{l}\text { Mean } \\
\text { percentage } \\
\text { "yes" }\end{array}$ & $n$ & $\begin{array}{l}\text { Mean } \\
\text { percentage } \\
\text { "yes"' }\end{array}$ \\
\hline Common Waxbill & 11 & $7 \cdot 3$ & $\mathrm{O}$ & - & 1 & 48.3 \\
\hline Royal Parrot Finch & 2 & $9 \cdot 5$ & 6 & 17.0 & 4 & 54.2 \\
\hline $\begin{array}{l}\text { Blue-faced Parrot } \\
\text { Finch }\end{array}$ & 6 & $7 \cdot 6$ & 5 & 14.0 & 1 & 46.6 \\
\hline $\begin{array}{l}\text { Chestnut-breasted } \\
\text { Mannikin }\end{array}$ & 11 & 11.9 & o & - & 1 & 41.9 \\
\hline $\begin{array}{l}\text { Black-headed } \\
\text { Mannikin }\end{array}$ & $11^{\mathrm{a}}$ & $9 \cdot 5$ & $\mathrm{O}$ & - & 1 & $67 \cdot 4$ \\
\hline
\end{tabular}

a including Malakula where the species was observed in 2000 (see Discussion).

and Epi; Blue-faced Parrot Finch on Efate; and Black-headed Mannikin on Santo. Chestnut-breasted Mannikin was not recorded during the formal observation sessions but was, nevertheless, seen on several other occasions on Santo. It attracted $41.9 \%(P<0.001)$ positive responses from local people on that island.

(ii) There was little evidence that estrildid species have extended their ranges during the past 40 years by colonizing islands where Bregulla (1992) did not record them, and there were no new species records on islands during the field studies (Table 2). Relatively few people on these islands claimed that the species concerned were present (Tables 4 and 6), with the sole exception of Black-headed Mannikin on Malakula. It had not been recorded there but $20.9 \%(P<0.05)$ of people interviewed claimed that it occurred locally.

(iii) There was, nevertheless, evidence that the ranges of two species have declined in recent years. Royal Parrot Finch may no longer occur on Aneityum, Malakula, Pentecost, Ambae and Santo, where Bregulla (1992) recorded it. None were observed on these islands during the present study and few local people claimed that it was present. However, data from Ambrym are ambiguous. The species was not recorded there but $38.2 \%(P$ $<0.001$ ) of people claimed that it was still resident. Blue-faced Parrot Finch was not seen on Emae, Ambrym and Ambae, where Bregulla (1992) recorded it. Furthermore, few islanders claimed that it occurred there, and it may have become locally extinct. It may still be present on Aneityum and Tanna because, although it was not seen on these islands, significant proportions of the local people (21.9\% and $28.9 \%$ respectively) claimed that it was there $(P<0.05$ and 0.001 respectively).

Field records suggest that there were differences in habitat choice in different species. Royal Parrot Finch was seen only within the forest or on the outskirts of 
villages (Table 5). Blue-faced Parrot Finch was recorded in forest habitats but was also seen in some urban areas outside formal recording sessions. In particular, large numbers foraged on the fairways of the golf course at Mele (on Efate). Common Waxbill and Black-headed Mannikin were common in areas of cleared forest, agricultural land and roadside verges on Efate and Santo respectively. These were also the habitats in which Chestnut-breasted Mannikin occurred on Santo.

\section{Discussion}

The results of this study suggest that local knowledge can be used as an inexpensive rapid appraisal method for assessing the distribution of birds in habitats that are difficult to survey but are inhabited by human populations. However, it should be noted that the technique is an indicator only of the presence or absence of species at specific locations. It cannot be equated with the precise information from the positive records that are returned by trained observers. The technique also depends on good environmental knowledge in the participants. This was evident in ni-Vanuatu, especially men. They spend a great deal of their time hunting in the forest and tending village gardens. The study therefore provided another example of the value of "traditional" knowledge in cultures in which it remains strong. It is used increasingly in environmental impact assessment (Stevenson 1996, Zamparo 1996) and it has been argued that, wherever appropriate, it should be incorporated into modern environmental management plans (Ruddle 1998). However, local knowledge may be less effective as a means of detecting the presence/absence of species in cultures in which there has been significant "Western" influence because people in them have tended to lose their affinity with the environment (Evans and Birchenough 2001) and mostly have poor knowledge of the environment (Lucas 1987, Acury 1990, Lock 1993). For example, the technique was ineffective in indicating places on south-east Viti Levu (Fiji) where Pink-billed Parrot Finch Erythrura kleinschmidti may still occur (Birchenough pers. obs.). Villagers (many of whom commuted to Suva to work) had poor knowledge of birds and were unable to recognize many of the common species that were resident in the area.

The technique can almost certainly be adapted for species other than estrildid finches where people have good environmental knowledge. Indeed, it may be more powerful for species that are large, colourful and/or noisy (such as lorikeets), food species (such as doves and pigeons), or those of cultural significance (such as Barn Owl Tyto alba in Vanuatu), than small estrildid finches. There were, nevertheless, problems in using species that were non-resident on particular islands as "controls" in this study. They may have been recognized by people from visits to neighbouring islands, and incorrectly ascribed to their own island. We believe that the technique would be improved in future studies by selecting species as "controls" that have never been recorded on Vanuatu.

The distributions of the five study species, Royal Parrot Finch, Blue-faced Parrot Finch, Common Waxbill, Chestnut-breasted Mannikin and Black-headed Mannikin, assessed on the basis of local knowledge, conformed closely with those derived from actual sightings of the birds (Figure 2). There were, nevertheless, four cases in which statistically significant proportions of islanders claimed 


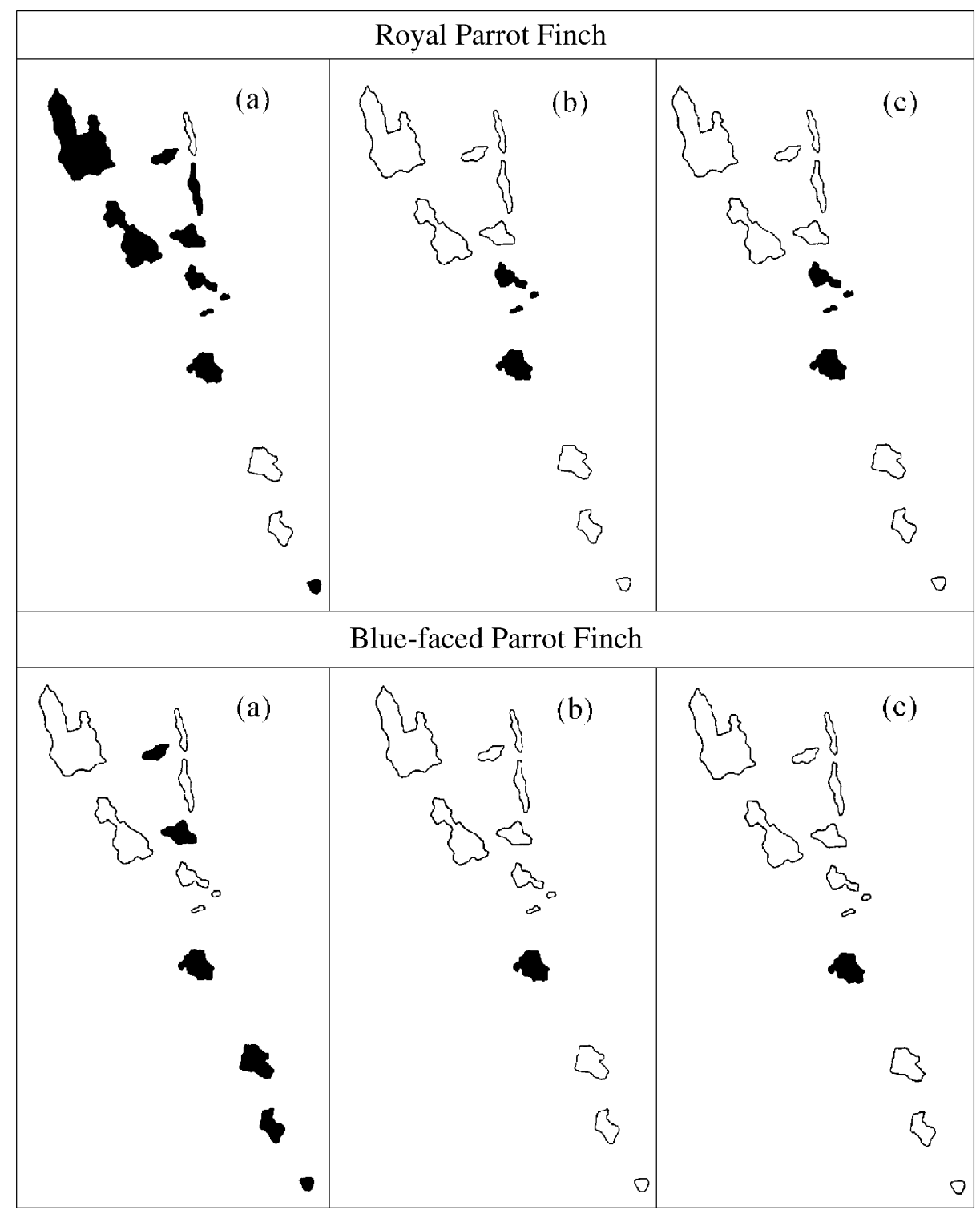

Figure 2. Distributions of two endemic subspecies of estrildid on Vanuatu: Royal Parrot Finch Erythrura cyanovirens regia and Blue-faced Parrot Finch Erythrura trichroa cyanofrons. Islands where the species occurs are shown in black. (a) distributions according to records in Bregulla (1992); (b) distributions based on the analyses of local knowledge; and (c) distributions based on sightings of finches in the present study.

that a species was present locally but it was not actually seen there by us. In three of these cases, Royal Parrot Finch on Ambrym, and Blue-faced Parrot Finch on Aneityum and Tanna, the species had been recorded on the islands in the past (Bregulla 1992). One possibility that would explain these data, is that the species have become locally extinct but they attracted relatively high numbers of 
positive responses because some people still remember them. Another possibility is that the species have become scarce and only some local people were aware of their presence. They were not recorded during the field recordings. Either possibility indicates that they have been declining in abundance and/or range in the past decade. In the fourth case, of Black-headed Mannikin on Malakula, the species had not been reported previously on the island (Bregulla 1992). However, it was seen on a return visit there in 2000 (Birchenough and Douglas pers. obs.). The species has therefore extended its range in Vanuatu. It was probably present in 1999 because, although it was not recorded during field studies, a significant proportion of local people recognized it as a resident species. It is interesting to note that the analysis of local knowledge was sufficiently sensitive to pick up this colonization before the species was actually recorded there by us. This suggests that data from surveys of local knowledge will be valuable in indicating the local presence or absence of a species even in the absence of complementary field studies.

The current status of estrildids on Vanuatu differs for different species. The three introduced species, Common Waxbill, Chestnut-breasted Mannikin and Black-headed Mannikin, appear to be at least holding their own. Populations of these introduced species have been established for the past three or four decades, although, with the exception of Black-headed Mannikin on Malakula, their ranges have evidently remained static. However, they are confined largely to human-modified habitats, such as agricultural land, cleared areas of forest and roadside verges, and are not normally seen within the forest itself. Such places are largely confined to the islands of Efate and Santo, where urban and agricultural development has been prevalent. The ranges of the two endemic subspecies, Royal Parrot Finch and Blue-faced Parrot Finch, are evidently in decline. There are several islands on which they had been recorded in earlier studies but where they no longer appear to be present (Figure 2). Thus, our data suggest that Royal Parrot Finch is now largely restricted to the group of islands, Efate, Emae, Tongoa, Epi and (probably) Ambrym. It was formerly present on Aneityum, Malakula, Pentecost and Ambae (Bregulla 1992). There have been occasional recent reports, usually of single birds on Santo and Gaua (BirdLife International 2000) but the species is certainly not common on either of these islands. The situation for Blue-faced Parrot Finch is similar. It is common on parts of Efate but may have "disappeared" from Emae, Ambrym and Ambae and, possibly, Aneityum and Tanna, in recent years.

The results of the study suggest that Royal Parrot Finch is in urgent need of conservation attention. It is particularly vulnerable to anthropogenic or natural change because of its small range, the fragmentation of its population into small island subpopulations and its specialist diet of figs. There are reports that birds have been captured illegally for the caged bird trade (BirdLife International 2000) but numbers are probably small and are unlikely to have had significant impacts on natural populations. Logging operations probably pose a greater threat and may be responsible for the demise of the species on Aneityum (Bregulla 1992). BirdLife International (2000) points out that loggers often leave fig trees standing but, even if the food source remains, it is still not clear whether the species can survive in cleared forest and agricultural land. There are reports that the Samoan subspecies of Royal Parrot Finch supplements its fig diet by feeding on intro- 
duced seeding grasses on track- and roadside verges (Evans et al. 1992), although the extent to which it could survive solely on grass seeds is unknown. It would in any case be unwise to depend on a natural dietary switch to conserve the species. Royal Parrot Finch was only observed in forests or on the outskirts of villages in this study and, while it was regularly seen feeding on figs, there is no evidence that it can supplement its diet in other ways. However, this is not the case for Blue-faced Parrot Finch. It is evidently more generalist in its feeding habits. It depends largely on seeding grasses (Bregulla 1992), and the occurrence of large numbers of this species foraging on a golf course on Efate suggests that it may be able to exploit introduced grasses and therefore benefit from urban development. Other estrildids have done so successfully, including Red Avadavat and Java Sparrow Padda oryzivora (both introduced species) in Fiji (Watling 1982), and Pintailed Parrot Finch Erythrura prasina in Borneo (Evans and Fidler 1990), the latter to such an extent that it has become a pest of paddy fields.

\section{Acknowledgements}

Our kind thanks to Mr Ernest Bani, Head of the Environment Unit, for his cooperation in this research. We would also like to thank Mr Chris Poll and other staff at the British High Commission for their support, and to Mike and Elisabeth Fidler, Peter Rindom and Pat Evans, for their contributions to the fieldwork. We sincerely thank Makoe Kalo and his family from Tongoa for their help, hospitality and friendship. The research is part of the Rare and Difficult Species (RADS) programme of the Australian Finch Society (U.K.), and it was supported by a grant from Autosmart International Ltd. We are most grateful to both organizations.

\section{References}

Acury, T.A. (1990) Environmental attitude and environmental knowledge. Hum. Org. 49: 300-304.

BirdLife International (2000) Threatened birds of the world. Barcelona and Cambridge, U.K.: Lynx Edicions and BirdLife International.

Bregulla, H.L. (1992) Birds of Vanuatu. Oswestry, U.K.: Anthony Nelson.

Canon, P.F. (1997) Strategies for rapid appraisal of fungal diversity. Biodivers. Conserv. 6: $669-680$.

Diamond, J.M. and Marshall, A.G. (1976) Origin of the New Hebridean Avifauna. Emu 76: $187-200$.

Evans, S.M. and Birchenough, A.C. (2001) Community-based management of the environment: lessons from the past options for the future. Aquat. Conserv.: Mar. Freshwat. Ecosyst. 11: 137-147.

Evans, S.M. and Fidler, M.E. (1990) Parrot finches. The aviculturist's guide. Poole, U.K.: Blandford.

Evans, S.M., Fletcher, F.J.C., Loader, P.J. and Rooksby, F.G. (1992) Habitat exploitation by landbirds in the changing Western Samoan environment. Bird Conserv. Internatn. 2: 123129 .

King, W.B. (1981) Endangered birds of the world: the ICBP bird red data book. Washington, D.C.: Smithsonian Institute Press and International Council for Bird Preservation. 
King, W.B. (1985) Island birds: will the future repeat the past? Pp. 3-15 in P.J. Moors, ed. Conservation of island birds. Cambridge, U.K.: International Council for Bird Preservation (Techn. Publ. 3).

Lock, R. (1993) Animals and the teaching of biological science in secondary schools. J. Biol. Educ. 27 : 112-114.

Lucas, A. (1987) Public knowledge of biology. J. Biol. Educ. 21: 41-45.

Oliver, I. and Beattie, A.J. (1996) Designing a cost effective invertebrate survey: a test of methods for rapid assessment of biodiversity. Ecol. Appl. 6: 594-607.

Preikshot, D., Nsiku, E., Pitcher, T. and Pauly, D. (1998) An interdisciplinary evaluation of the status and health of African lake fisheries using a rapid appraisal technique. $J$. Fish Biol. 53 (Suppl. A): 381-393.

Ruddle, K. (1998) The context of policy design for existing community-basedfisheries management systems in the Pacific islands. Ocean Coast. Manage. 40: 105-126.

Skilleter, G.A. (1996) Validation of rapid assessment of damage in urban mangrove forests and relationships with molluscan assemblages. J. Mar. Biol. Assoc. U.K. 76: 701-716.

Stattersfield, A.J., Gasby, H.J., Long, A.J. and Wege, D.C. (1998) Endemic Bird Areas of the world. Cambridge, U.K.: Birdlife International.

Stevenson, M.G. (1996) Indigenous knowledge in environmental assessment. Arctic 49: 278-291.

Turner, I.M., Wong, Y.K., Chew, P.T. and BinIbrahim, A. (1996) Rapid assessment of tropical rain forest succession status using aerial photographs. Biol. Conserv. 77: 177-183.

Van Dam, R.A., Camilleri, C. and Finlayson, C.M. (1998) The potential of rapid assessment techniques as early warning indicators of wetland degradation: a review. Environ. Toxicol. Water Qual. 13: 297-312.

Watling, D. (1982) Birds of Fiji, Tonga and Samoa. Wellington, New Zealand: Millwood Press.

Zamparo, J. (1996) Informing the fact: Inuit traditional knowledge contributes another perspective. Geosci. Canada 23: 261-266.

Ziswiler, V., Guttinger, H.R. and Bregulla, H. (1972) Monographie der Gattung Erythrura Swainson, 1873 (Aves, Passeres, Estrildidae). Bonner Zool. Monogr.2.

A.C. BIRCHENOUGH, G.W. DOUGLAS and S.M. EVANS

Dove Marine Laboratory (School of Marine Science and Technology, Newcastle University), Cullercoats, Tyne and Wear, NE3o 4 PZ, U.K.

Email: A.C.Birchenough@ncl.ac.uk

Received 21 February 2002; revision accepted 23 September 2002 